\title{
Evaluation of Some Plant Extracts and Powders in Control of Bean Damping-Off By Sclerotinia Sclerotiorum
}

\author{
Zahra Ibrahim El-Gali \\ Dept. of Plant Protection, Faculty of Agriculture, Omer AlMuhktar University. El-Beida, Libya \\ Email:Zahra.Ibrahim@omu.edu.ly
}

\begin{abstract}
The antifungal effect of three botanical powdered plants and their aqueous extracts against damping-off disease incidence of bean were evaluated under laboratory and field conditions. Also This study investigated the phytochemical profile of these plants. Powder of Peganum harmala, Urtica dioica and Helichrysum stoechas leaves were used in the present work. The botanical plant extracts were applied as seed dressing, while the powders were applied as seed coating in vitro or were added to the cultivation soil in vivo before or after inoculation with Sclerotinia sclerotiorum then sowing. All applied treatments reduced dead seedlings incidence comparing with untreated control. Higher significant reduction in disease incidence was observed for $H$. stoechas treatment than that of the others plants. It is interesting to note that botanical plants extract gave a similar effect to the powder in reducing disease incidence either at pre- or post-emergence stages of bean growth. The content of the active biological compounds different between all plants.
\end{abstract}

Keywords: Plant extract, Powder, Phytochemical, Damping-off, Sclerotinia sclerotiorum

Citation | Zahra Ibrahim El-Gali (2018). Evaluation of Some Plant Extracts and Powders in Control of Bean Damping-Off By Sclerotinia Sclerotiorum. Agriculture and Food Sciences Research, $5(1): 47-51$.

History:

Received: 13 March 2018

Revised: 7 April 2018

Accepted: 9 April 2018

Published: 12 April 2018

Licensed: This work is licensed under a Creative Commons

Attribution 3.0 License $($ co)

Publisher:Asian Online Journal Publishing Group
Funding: This study received no specific financial support

Competing Interests: The author declares that there are no conflicts of interests regarding the publication of this paper.

Transparency: The author confirms that the manuscript is an honest, accurate, and transparent account of the study was reported; that no vital features of the study have been omitted; and that any discrepancies from the study as planned have been explained.

Ethical: This study follows all ethical practices during writing.

\section{Contents}

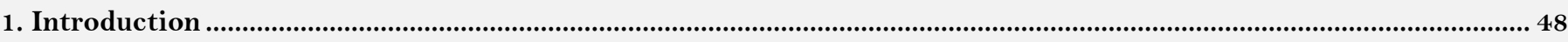

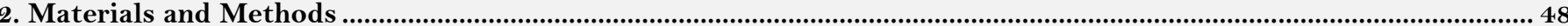

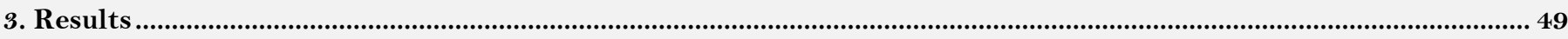

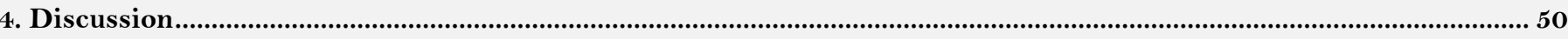

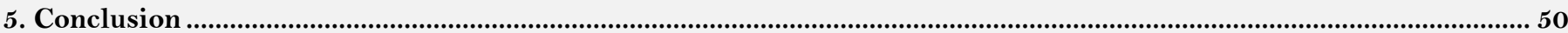

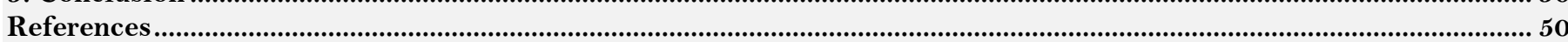




\section{Introduction}

Dry white bean (Phaseolus vulgares L.) is one of the major protein yielding plant found not only in Libya but throughout the world due to the presence of high calorie protein. Sclerotinia sclerotiorum is an important fungal pathogen with cosmopolitan distribution that has a wide host range [1-3]. Damping-off and root rot disease caused by $S$. sclerotiorum is a serious and persistent diseases problem of bean plants during growing season. Control of such diseases mainly depend on fungicidal treatments [4]. However, fungicidal applications cause hazards to human health and increase environmental pollution. Therefore, alternative treatments for control of plant diseases are needed [5]. Botanical plants made into powder were widely used by ancient civilizations to improve the palatability of foods and beverages as well as for their preserving characteristics. Various plant products like gum, oil, resins etc. are used as fungicidal agents [6-8]. The biological control of plant diseases may have minimum adverse effect on physiological processes of plant and less environmental hazards [9]. The objective of the research work performed was to study the antifungal activity of some botanical plant extracts and powders against damping-off disease incidence of bean in vivo and in vitro conditions.

\section{Materials and Methods \\ 2.1. Source of Pathogen}

S. sclerotiorum was isolated from dry bean seeds and identified in laboratory of phytopathology, Faculty of Agriculture, Omer AlMukhtar University, Libya.

\subsection{Plant Materials}

\subsubsection{Preparation of Powders}

Three different plant species, Peganum harmala, Urtica dioica and Helichrysum stoechas known for their medicinal value in traditional medicine and generally available in wild in Al-Jabal Al-Akhdaer region were selected for the study (Fig. 1). The apparently healthy leaves of these plants were collected in flowering time, then washed thoroughly with running tap water to remove the dust and dried. The dried leaves, were crushed into powder with the help of grinder. The powders were passed through sieve to get fine powder. The powders of different plant were stored in polythene bags for the study.

\subsubsection{Preparation of Aqueous Extracts}

Fifty grams of each of above mentioned botanical plant materials in powder form was homogenized by laboratory blender in $50 \mathrm{ml}$ distilled water for $10 \mathrm{~min}$, then left in dark place for $24 \mathrm{~h}$ for tissue maceration. The extracts were filtered through thin cheesecloth sheets. The final extracts/supernatant were filtered through Whatman No. 1 filter paper and sterilized by Zeits filter $(0.24 \mu \mathrm{l})$, then collected separately in sterile dark glass tight bottles. The obtained extracts served as the crude extract (100\% concentration) and kept in a refrigerator at $4^{\circ} \pm 1$ until use.

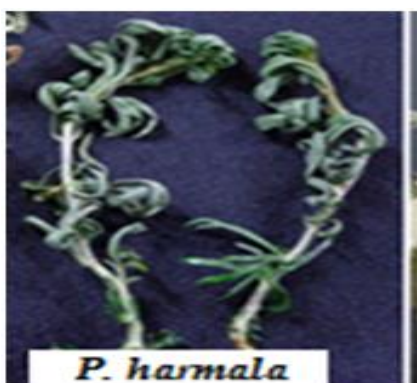

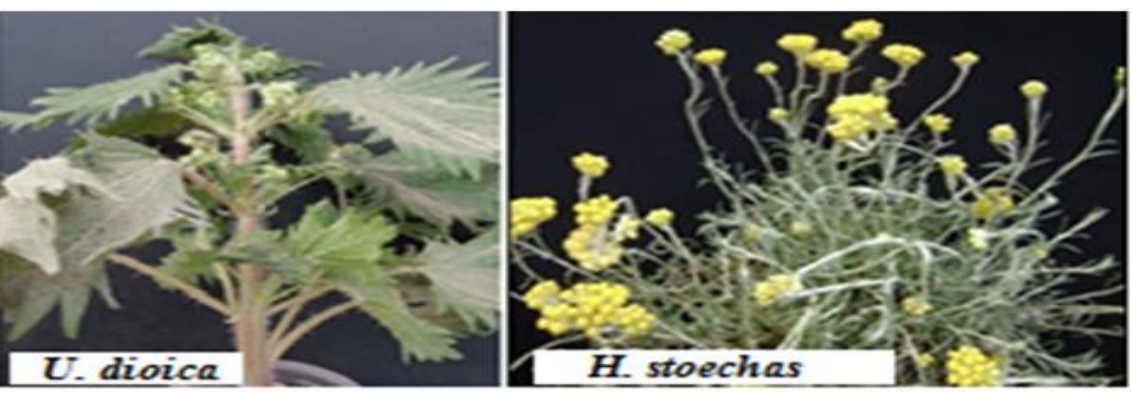

Fig-1. Types of used plants

\subsection{Application of Plant Materials for Damping-Off Control \\ 2.3.1. Laboratory Experiment}

The plant materials were evaluated for bean damping-off control by using different methods of application. The wet method depends on soaking the bean seeds in the plant extract for 12, 24 and 36h., then left for $1 \mathrm{~h}$ to dry, and in pure water for check treatment. The dry method depends on mixing the seed with the formula, Carboxy Methyl Cellulose (0.1 g CMC in $10 \mathrm{ml}$ water) as adhesive material. and were rolled on plant powder to help it for adhesion. For studying the disease in lab., Petri plates with Potato Sucrose Agar medium were inoculated with S. sclerotiorum and incubated at $23 \pm 2^{\circ} \mathrm{C}$. when the entire plate was covered with the white mycelium, the mycelial mat was covered with sterilized soil, $1.0 \mathrm{~g}$ thick. Soaked and coated seeds were germinated in plates and incubated at room temperature, four replicates were used for each treatment. In control plates, the seeds without treatment were planted in plates medium.

\subsubsection{Field Experiment}

Under field conditions, plastic pots (15 cm diam.) were used. Pots were sterilized by immersing in $5 \%$ formalin solution for $15 \mathrm{~min}$., and left several days before being used, then filled with sterilized sand and clay soil (1:1 v/v). The soil had infestation of 5 fungus sclerotia and irrigated for one week before sowing. The seeds soaked were sown at rate of 5 seeds/ pot. The botanical plant powder tested was applied by two methods: a) Soil mixed with powder at rate of $3 \mathrm{~g}$ powder/ $300 \mathrm{~g}$ and left two days before infestation with sclerotia and irrigated for one week. b) Soil infested with sclerotia and irrigated for one week before powder added. Surface sterilized seeds were planted at the rate of 5 seeds per pot in two applications. 


\subsection{Disease Assessments}

Disease effects due to $S$. sclerotiorum in the different treatments were assessed at 10 days after planting as decayed seeds, death of seedlings (pre and post emergence) and seedling survival after 30 days. These parameters were calculated and expressed as percentages.

\subsection{Data Analysis}

All experiments were conducted on the basis of completely randomized designs (CRD). Each treatment was replicated at least five times. For statistical analysis, data were subjected to the analysis of variance (ANOVA) using Co Stat Program. Angular transformed values were used for data analysis. Statistical comparisons among means were performed using Duncan's multiple range test (DMRT).

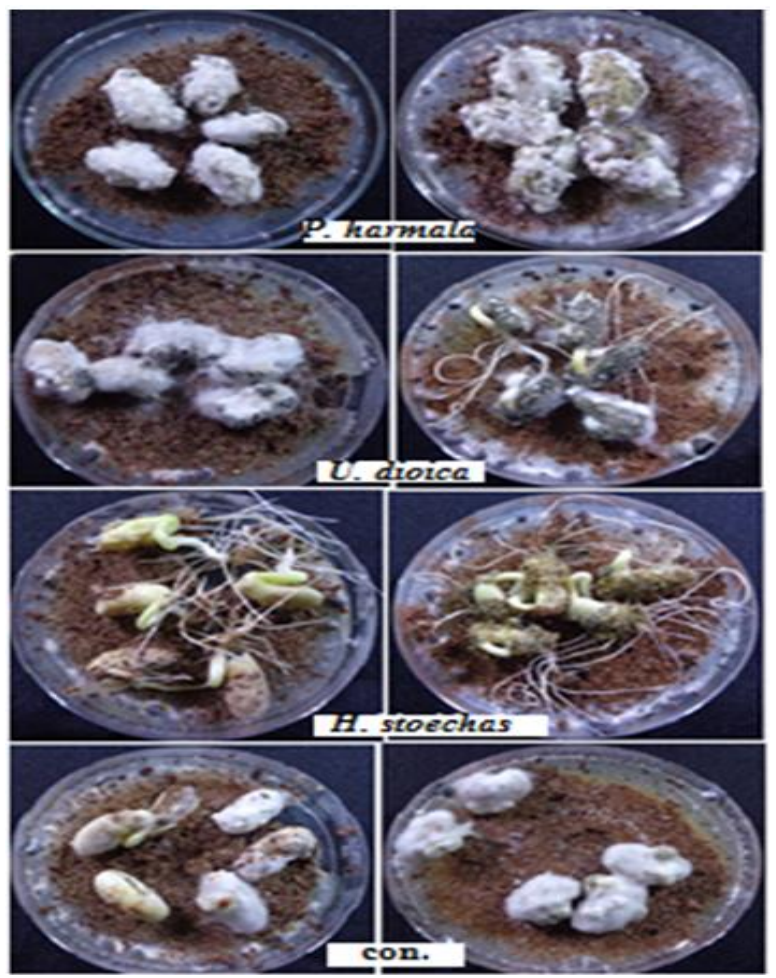

Fig-2. Effect of plant extracts and powders on seed decay. (Source: The photograph was took by Author's camera)

\subsection{Phytochemical Analysis}

Phytochemical analysis of the extracts was done by following the methods described previously [10-14].

\section{Results}

From observations in the test, after 10 days, all the seeds had not grown in the plate treated with $P$. harmala and in the control plates, and it appeared completely decay. The dressing with H. stoechas was protected the seed against fungus invasion. In the treatment plates, $U$. dioica powder was effect in reduce seed decay than plant extract, while extract and powder of H. stoechas was the best in control seed decay disease (Fig. 2).

The decrease in seeds rot was observed in seeds that were treated with extract or coated with powder of $H$. stoechas, at ratio of $20 \%$ and $6.7 \%$ compared with $100 \%$ in control treatment (Table 1). H. stoechas was more effective than others plants against seeds decay.

\begin{tabular}{|c|c|c|c|c|}
\hline \multirow{3}{*}{ Treatments } & \multirow{2}{*}{\multicolumn{3}{|c|}{$\begin{array}{c}\text { Extract } \\
\text { Time (h) }\end{array}$}} & \multirow{3}{*}{ Powder } \\
\hline & & & & \\
\hline & 12 & 24 & 36 & \\
\hline P. harmala. & $100(100.0) \mathrm{a}$ & $100(100.0) \mathrm{a}$ & $100(100.0) \mathrm{a}$ & $93.3(75.00) \mathrm{a}$ \\
\hline U. dioica & $86.7(68.53) \mathrm{a}$ & $93.3(75.00) \mathrm{a}$ & $100(100.0) \mathrm{a}$ & $33.3(35.24) . \mathrm{b}$ \\
\hline H. stoechas & $20.0(26.56) \mathrm{b}$ & $20.0(26.56) \mathrm{b}$ & $20.0(26.56) \mathrm{b}$ & $06.7(15.00) \mathrm{b}$ \\
\hline Con. & $93.3(75.00) \mathrm{a}$ & $93.3(75.00) \mathrm{a}$ & $100(100.0) \mathrm{a}$ & $100(100.0) \mathrm{a}$ \\
\hline LSD at $5 \%$ & 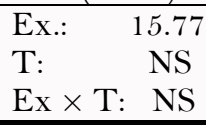 & & & 28.95 \\
\hline
\end{tabular}

Note: Each value is mean of four replicates

Percentage of infection transformed data by the arcsine square before analysis. NS: Non-significant

Results in Table (2) indicate that the treatment with H. stoechas was significantly reduced the seed decay disease of bean plants comparing with treatments with $P$. harmala and $U$. dioica and untreated check control treatment. It recorded disease incidence $(33.3,28$ and $4 \%)$ and seedling healthy $(66.7,72.60 \%)$ in both ex tract and powder compared with $86.7 \%$ dead Seedlings and $13.3 \%$ seedlings healthy in control treatment. In terms of effect of extracts and powders on disease in field the study recorded occurrence the reduction in seedlings death and increased seedlings survival after seeds treatment with extract or soil amended with powder before or after inoculation with fungal sclerotial. The H. stoechas weed was more effective followed by $U$. dioica. 
Table-2. Effect of dressing bean seeds with plant preparation on percentage of bean damping-off disease

\begin{tabular}{|c|c|c|c|c|c|c|}
\hline \multirow{4}{*}{ Treatment } & \multicolumn{6}{|c|}{ Formula tested } \\
\hline & \multirow{2}{*}{\multicolumn{2}{|c|}{ Suspension }} & \multicolumn{4}{|c|}{ Powder } \\
\hline & & & \multicolumn{2}{|c|}{ Before inoculation } & \multicolumn{2}{|c|}{ After inoculation } \\
\hline & $\begin{array}{c}\text { Dead } \\
\text { Seedlings } \\
\end{array}$ & $\begin{array}{c}\text { Seedlings } \\
\text { healthy }\end{array}$ & $\begin{array}{c}\text { Dead } \\
\text { Seedlings }\end{array}$ & $\begin{array}{c}\begin{array}{c}\text { Seedlings } \\
\text { healthy }\end{array} \\
\end{array}$ & $\begin{array}{c}\text { Dead } \\
\text { Seedlings }\end{array}$ & $\begin{array}{c}\text { Seedlings } \\
\text { healthy }\end{array}$ \\
\hline P. harmala. & $60.0(50.77) \mathrm{ab}$ & $40.0(39.23) \mathrm{ab}$ & $48.0(43.85)$ & $52.0(46.15)$ & $88.0(69.73)$ & $\begin{array}{l}12.0 \\
(20.27)\end{array}$ \\
\hline U. dioica & $73.3(58.89) \mathrm{ab}$ & $26.7(31.11) b c$ & $40.0(39.23)$ & $60.0(50.77)$ & $36.0(36.87)$ & $\begin{array}{l}64.0 \\
(53.13)\end{array}$ \\
\hline H. stoechas & $33.3(35.21) \mathrm{b}$ & $66.7(54.76) \mathrm{a}$ & $28.0(31.95)$ & $72.0(58.05)$ & $40.0(39.23)$ & $\begin{array}{l}60.0 \\
(50.77)\end{array}$ \\
\hline Con. & $86.7(68.70) \mathrm{a}$ & $13.3(31.39) \mathrm{c}$ & $86.7(68.70)$ & $13.3(31.39)$ & $86.7(68.70)$ & $\begin{array}{l}13.3 \\
(31.39)\end{array}$ \\
\hline LSD $5 \%$ & 24.9 & 17.4 & $\begin{array}{l}\text { Method: } \\
\text { Treatment: } \\
\mathrm{M} \times \mathrm{T}:\end{array}$ & $\begin{array}{l}\text { NS } \\
16.79 \\
\mathrm{NS}\end{array}$ & $\begin{array}{l}\text { Method: } \\
\text { Treatment: } \\
\mathrm{M} \times \mathrm{T}:\end{array}$ & $\begin{array}{l}\text { NS } \\
11.88 \\
\text { NS }\end{array}$ \\
\hline
\end{tabular}

Note: Each value is mean of three replicates.

Percentage of infection transformed data by the arcsine square before analysis

Values followed by the same letter(s) are not significantly different at $\mathrm{P}=0.05$.

NS: Non-significant.

Phytochemical properties of extracts of P. harmala, $U$. dioica and H. stoechas are represented in Table (3). Flavonoids were not found in $P$. harmala and $U$. dioica but were found to be the major phytoconstituent along with glycosides, phenols, tannins, resins and terpenoids in H. stoechas. Saponins were present as the major phytoconstituents irrespective of $P$. harmala and $U$. dioica. P. harmala extract was poorer in antifungal compounds.

Table-3. Phytochemical constituents of aqueous extracts of different plants

\begin{tabular}{l|c|c|c}
\multicolumn{1}{r}{ Table-3. Phytochemical constituents of aqueous extracts of different plants } \\
\hline Compound & $\boldsymbol{P}$. harmala. & $\boldsymbol{U}$. dioica & H. stoechas \\
\hline Alkaloids & + & - & - \\
\hline Anthraquinones & - & - & - \\
\hline Flavonoids & - & - & + \\
\hline Glycosides & - & + & + \\
\hline Phenols & - & + & - \\
\hline Saponins & + & + & + \\
\hline Tannins & - & + & + \\
\hline Terpenoids & - & + & + \\
\hline Phlobatanins & - & - & + \\
\hline Resins & - & + & \\
\hline
\end{tabular}

\section{Discussion}

Naturally occurring products from plants have played an important role in the discovery of new therapeutic agents since ancient times. The use of plant extracts and phytochemicals, with known antimicrobial properties, may be of immense importance in therapeutic treatments. Synthetic fungicides are currently used as the primary means for the control of plant diseases. However, the alternative control methods are needed because of the negative public perceptions about the use of synthetic chemicals, resistance to fungicides among fungal pathogens, and high development cost of new chemicals. The uses of plant derived products as diseases control agents have been studied, since they tend to have low mammalian toxicity, less environmental effects and wide public acceptance [5]. To develop environment-friendly alternatives to synthetic fungicides for the control of fungal plant diseases, the interest on essential oils and plant extracts has been increased [9]. The results obtained in the present work indicate that the powders were more effective than extracts. This results agreement with that obtained by ElMougy and Abdel-Kader [15] and Mokhtar, et al. [16]. H. stoechas extract or powder had antifungal activity against plant pathogenic fungus tested in the present study. Numerous studies have been conducted in the past few years to prove such efficiency [17-20]. Plant of the genes Helichrysum are prolific producer secondery metabolites as antiviral, antifungal, antimicrobial and anti-inflammatory [20-23]. The efficiency of $H$. stoechas may be due to the high content of phenols, flavonoids, glycosides, tannins, terpenids and resins in leaves more than the others plants. So, it is interested to state that we can used H. stoechas extracts and/or powders less expensive for controlling plant diseases under field.

\section{Conclusion}

Promising applicable technique could be suggested in the light of the results obtained. The use of soil drench treatment with botanical plants powder might be considered as safe, cheap and easily applied method for controlling such soil-borne plant pathogens as eco-friendly means, and considering the avoidance of environmental pollution and the side effect of pesticide

\section{References}

[1] M. Malvárez, I. Carbone, N. J. Grünwald, K. V. Subbarao, M. Schafer, and L. M. Kohn, "New populations of Sclerotinia sclerotiorum from lettuce in California and peas and lentils in Washington," Phytopathology, vol. 97, pp. 470-483, 2007. View at Google Scholar $\mid$ View at Publisher

[Q] Z. I. El-Gali, "Cultural, morphological and Physiological studies on some isolates of sclerotinia sclerotiorum Libyan," Journal of Plant Protection Research, vol. 1, pp. 11-16, 2010. 
M. M. Abdel-Kader, N. S. El-Mougy, and S. M. Lashin, "Chemical and biological measures against sclerotinia spp. The causal of foliage blight disease of cucumber and pepper plants in Egypt- A review," International Journal of Engineering $\mathcal{E}^{\circ}$ Technology, vol. 3, pp. 302- $311,2014$. B. A. Rauf, "Seed-borne disease problems of legume crops in Pakistan," Pakistan Journal of Scientific and Industrial Research, vol. 43, pp. 249-254, 2000. View at Google Scholar

N. S. El-Mougy, F. Abd-El-Karem, G. E. Nadia, and Y. O. Fotouh, "Application of fungicides alternatives for controlling cowpea root rot diseases under greenhouse and field conditions," Egyptian Journal of Phytopathology, vol. 32, pp. 23-35, 2004. View at Google Scholar

D. Yazdani, Y. H. Tan, M. A. Zainal Abidin, and I. B. Jaganath, "A review on bioactive compounds isolated from plants against plant pathogenic fungi," Journal of Medicinal Plants Research, vol. 5, pp. 6584-6589, 2011. View at Google Scholar

D. Hada and K. Sharma, "A review: Plant extracts a new source of antimicrobial potential," Research Journal of Pharmaceutical, Biological and Chemical Sciences (RJPBCS), vol. 5, pp. 597- 628, 2014. View at Google Scholar

D. Hassan, M. N. Galti, and B. Ali, "Use of Neem (Azadirachta Indica) seed powder to treat groundnut seed-borne pathogenic fungi," European Journal of Experimental Biology, vol. 5, pp. 69-73, 2015. View at Google Scholar

[9] S. K. Okwute, Plants as potential sources of pesticidal agents: A Review. Chapter 9, In Pesticide - Advances in Chemical and Botanical Pesticides. Idu, Abuja, Nigeria: National Institute for Pharmaceutical Research and Development, 2012.

[10] I. M. Shihata, "A pharmacolog-ical study of anagallis arvensis," MS.c. Thesis, Faculty of Vet. Med, Cairo University, Egypt, 1951.

[11] G. E. Trease and W. C. Evans, Pharmacognosy. Pytochemistry: Introduction in general methods, 11 th ed. London: Bailliere Tindll. pp: $227-247,2002$.

[12] J. B. Harbone, Phytochemical methods. London: Chapman and Hall. pp: 183 - 195, 1973.

[13] H. O. Edeoga, D. E. Okwu, and B. O. Mbaebie, Phytochemical constituents of some Nigerian medicinal plants. African Journal of Biotechnology, vol. 4, pp. 685-688, 2005.

[14] J. U. Ewansiha, S. A. Garba, M. Galadima, S. Y. Daniyan, and M. B. Busari, "Therapeutic potency of citrus Limon (L) Burm. F. (Lemon) peel extract against some disease causing microorganisms," International Journal of Research Studies in Biosciences, vol. 4, pp. 30-39, 2016.

[15] N. S. El-Mougy and M. M. Abdel-Kader, "Antifungal effect of powdered spices and their extracts on growth and activity of some fungi in relation to damping-off disease control," Journal of Plant Protection Research, vol. 47, pp. 267-278, 2007. View at Google Scholar

[16] M. M. Mokhtar, N. S. El-Mougy, F. Abdel-Kareem, N. G. El-Gamaal, and Y. O. Fatouh, "Effect of some botanical powdered plants against root rot disease incidence of bean under field conditions," International Journal of Engineering $\S^{\circ}$ Technology, vol. 4, pp. 162167, 2014. View at Google Scholar

[17] A. Bogdadi, L. Kokoska, J. Havlik, P. Kloucek, V. Rada, and K. Vorisek, "In Vitro antimicrobial activity of some Libyan medicinal plant extracts," Pharmaceutical Biology, vol. 45, pp. 386-391, 2007. View at Google Scholar $\mid$ View at Publisher

[18] S. AlBayrak, A. Aksoy, O. Sağdic, and U. Budak, "Phenolic compounds and antioxidant and antimicrobial properties of Helichrysum species collected from eastern anatolia, Turkey," Turkish Journal of Biology, vol. 34, pp. 463-473, 2010. View at Google Scholar

[19] M. Buzayan and F. El-Garbulli, "Antibacterial activity of medicinal aqueous plant extracts against Mycobacterium tuberculosis," Malaysian Journal of Microbiology, vol. 8, pp. 203-206, 2012. View at Google Scholar

[20] D. J. Bigović, T. R. Stević, T. R. Janković, N. B. Noveski, D. S. Radanović, D. S. Pljevljakušić, and Z. R. Djurić, "Antimicrobial activity of Helichrysum plicatum DC," Hemijska industrija, vol. 71, pp. 337-342, 2017. View at Google Scholar |View at Publisher

[21] A. Sala, M. C. Recio, G. R. Schinella, S. Manez, and G. R.M., "Assessment of the antiflammatory activity and free radical scavenger activity of tiliroside," European Journal of Pharmacology, vol. 641, pp. 53- 61, 2003. View at Google Scholar | View at Publisher

[22] S. F. Van Vurren, A. M. Viligoen, F. R. Van Zyl, K. Van Heerden, K. Husnu, and C. Baser, "The antimicrobial, antimalarial and toxicity profiles of helihumulone, leaf essential oil and extracts of Helichrysum oymosum (L.) D. Don subsp. oymosum," South African Journal of Botany, vol. 72, pp. 287- 290, 2006. View at Google Scholar $\mid$ View at Publisher

[23] E. A. Sobhy and S. S. El-Feky, "Chemical constituents and antimicrobial activity of helichrysum stoechas," Asian Journal of Plant Sciences, vol. 6, pp. 692-695, 2007. View at Google Scholar | View at Publisher 